Article

\title{
An Exploratory Study of Cooperative Survival: Strategic Adaptation to External Developments
}

\author{
Jasper Grashuis \\ Department of Agricultural and Applied Economics, University of Missouri, Columbia, MO 65211, USA; \\ grashuisj@missouri.edu; Tel.: +1-573-882-7740
}

Received: 15 January 2018; Accepted: 26 February 2018; Published: 28 February 2018

\begin{abstract}
Farmer cooperatives have been portrayed in the literature as flawed and complex organizations with ambiguous objectives. However, research on the observed survival of farmer cooperatives in spite of their weaknesses and limitations is scarce, in part because academic attention to cooperative performance has been static and introspective. Using evidence collected from case studies and print media publications, this paper contributes to the literature with a qualitative study of farmer cooperatives which spurred survival and longevity by means of strategic adaptation in response to four current developments in the external environment: industry consolidation, consumer segmentation, price volatility, and policy change. The qualitative study concludes farmer cooperatives in general respond to such developments by means of organizational growth. Common strategies are vertical integration, geographic expansion, and portfolio diversification. While survival and longevity are promoted in theory, strategic adaptation also often facilitates the pursuit of investor-oriented as opposed to user-oriented objectives. In some scenarios, member ownership and control may become burdensome to the business and prompt conversion to another structure if further adaptation to internal and external developments is unsuccessful. More research is therefore needed to explore the dynamic and variable impact of strategy on cooperative survival.
\end{abstract}

Keywords: agricultural cooperative; firm survival; strategy; external adaptation; coevolution

\section{Introduction}

Organized farm producers have formed cooperatives to solve the problems of low bargaining power in input supply and output demand sectors for over 100 years [1]. Over time, farmer cooperatives have become successful and even dominant in Europe and the United States [2-4], and evidence of their importance in the developing world is mounting $[5,6]$.

However, the future survival of farmer cooperatives is by no means guaranteed. As indicated by the theoretical as well as the empirical literature [6,7], farmer cooperatives are flawed and complex business organizations with ambiguous objectives. Current developments in the agri-food industry expose their various weaknesses and limitations and may impact their survival. For example, with ongoing consolidation at every stage of the value chain [8], many farmer cooperatives must overcome equity constraints to make investments in scale and scope economies for greater efficiency and competitiveness [9]. Also, the segmentation of critical food consumers necessitates a strong market orientation [10], but most farmer cooperatives have an inherent upstream bias [11,12]. Moreover, many farmer cooperatives see increasing heterogeneity in member attitudes and objectives $[13,14]$.

Such developments may impact the relative efficiency of farmer cooperatives in the agricultural sector. Despite their various weaknesses and limitations, how do so many farmer cooperatives reach the "century milestone" [15]? While dozens of farmer cooperatives exit each year by means of mergers, acquisitions, liquidations, and bankruptcies [16], why and how might others survive? Some researchers have informed solutions to internal inefficiencies [17], and there exist scattered 
observations of joint responses to external developments. Overall, however, there is no study in which the full range of possible responses to external developments is examined. The scarcity is in part explained by the fact most empiricists and theoreticians assume a static and introspective view of cooperative performance [6,7], which implies a general disregard for dynamic equilibria and external developments. Following recommendations by Abatecola et al. [18] and McCarthy et al. [19] regarding the adoption of a co-evolutionary and multidisciplinary view of business survival and longevity, this paper addresses the gap in the literature with a qualitative study of dynamic and strategic adaptation to external developments by farmer cooperatives in the context of survival and longevity. Specifically, the research question is as follows: How have farmer cooperatives responded to industry consolidation, consumer segmentation, price volatility, and policy change to spur survival and longevity? The research question is addressed with a qualitative study of evidence collected from case studies and print media publications to inform possible manifestations of external or strategic adaptation. Correspondingly, the character of the study is exploratory as opposed to explanatory.

The contribution of this paper is manifested by the qualitative study of strategic adaptation by farmer cooperatives, a topic which has not received much explicit attention in the academic literature. Using secondary data collected from case studies and print media publications, the qualitative study informs possible responses to industry consolidation, consumer segmentation, price volatility, and policy change by farmer cooperatives in North America, Europe, and Australia. The study concludes farmer cooperatives in general respond to developments in the external environment by means of organizational growth. In particular, geographic expansion, portfolio diversification, and vertical integration are three common strategies used by farmer cooperatives to spur survival and longevity in the agri-food value chain. In doing so, however, farmer cooperatives may become susceptible to more internal inefficiencies which may, paradoxically, accelerate the path toward exit if further adaptation is unsuccessful. The inherent equity constraint of farmer cooperatives in particular is magnified by organizational growth. However, the continued existence of Arla, CHS, Danish Crown, Fonterra, Sodiaal, and other large and successful farmer cooperatives is suggestive of the ability of organized farm producers to adapt to dynamic as opposed to static situations.

The paper proceeds as follows. Section 2 provides a background of the internal and external characteristics of farmer cooperatives as well as the frameworks of economic adaptation and organizational change. The methodology is described in Section 3. Section 4 discussed the various manifestations of external adaptation by farmer cooperatives. Section 5 extends the discussion of strategic adaption to cooperative ownership, governance, and finance. Finally, Section 6 provides a summary and conclusion, including a discussion of future research directions.

\section{Background}

\subsection{Internal and External Characteristics of Farmer Cooperatives}

Following observations of the ownership and governance of user-owned and user-controlled organizations by Jensen and Meckling [20], Vitaliano [21], Staatz [22], and Porter and Scully [23], Cook [24] identified five common collective action problems: (i) the free rider problem, (ii) the horizon problem, (iii) the portfolio problem, (iv) the control problem, and (v) the influence problem. The first three problems form an equity problem, and the latter two an agency problem. Each of the problems is caused by heterogeneous member attitudes and objectives, which are manifested by differences in various characteristics such as farm size, risk attitude, wealth, experience, political affiliation, and others [13]. Driven by organizational growth, member heterogeneity may cause degeneration if farmer cooperatives do not adapt successfully [25].

Farmer cooperatives also face external challenges. Because of their open membership policy, many traditional cooperatives attract low quality producers and are, therefore, less competitive in the differentiated product market [26]. While a strong market orientation is necessary in case of stiff competition [10], most members have an inherent upstream bias and often perceive the cooperative as an 
extension of the farm as opposed to an independent firm with its own objectives. Traditional cooperatives are thus likely to be user- or member-oriented as opposed to market-oriented [27]. By extension, few members have an incentive to invest or retain equity in the cooperative to make collective investments in branding, research and development, or other activities with long-term payoffs [28]. Therefore, farmer cooperatives in general have relatively weak brand equity [11,29], which is problematic as competition in the agri-food industry is increasingly driven by product differentiation.

\subsection{Economic Adaptation and Organizational Evolution}

According to Williamson [30], effective adaptation to the external environment is a first order objective of economic organization. Williamson's [30] interpretation is based on the work of Barnard [31] and Hayek [32], who emphasized two different types of economic adaptation. To Barnard [31], the purpose of economic organization is the internal adaptation to different expectations or interpretations of supply and demand dynamics. The consequence of such differences is failure of the input-output coordination process, which implies economic inefficiency. By contrast, Hayek [32] stressed external adaptation, the processing of supply and demand interactions to efficiently use the price mechanism. In context of the economic organization, the two interpretations of economic adaptation are interrelated as imperfect alignment or coordination of the input-output process has a negative impact on the ability to collectively react to market conditions.

The apparent interrelationship of internal and external adaptation is related to the relatively novel paradigm of organizational co-evolution, which constitutes a compromise of the selection view and the adaptation view [18]. According to the co-evolution view, an organization is efficient as long as there is alignment with dynamic external conditions. By extension, evolution and survival are determined by the ability of organizations to adapt to the dynamic environment as change is assumed to occur continuously. Overall, emphasis is thus placed on dynamic as opposed to static equilibria. There is growing academic interest in co-evolution as the business environment has increased in complexity and volatility [18], warranting a broader perspective to explain real-world situations. The primary advantage of adopting the co-evolution view is the ability to integrate micro- and macro-level evolution within a single framework [33]. In the marketing and strategic management literature, simultaneous consideration of internal and external adaptation constitutes a combination of industrial organization and theory of the firm paradigms (e.g., [34]). Empirically, the paradigm of organizational co-evolution is most often manifested by the case study approach to inform qualitative observations [18]. In terms of competition and performance, common conceptualizations are strategic renewal, technological innovation, absorptive capacity, and network formation [35].

\section{Methodology}

As noted in the introduction, evidence of external adaptation by farmer cooperatives is rarely presented from an organizational change perspective. Therefore, we first performed a wide search of the term "agricultural cooperative" and several synonyms in Scopus, ScienceDirect, EBSCOhost, Web of Science, Google Scholar, and ProQuest, using three search criteria: (i) the publication is in English, (ii) the publication is peer-reviewed, and (iii) the publication is from the year 2000 or after (the year 2000 is used as an intuitive cutoff so as to emphasize results and findings with strong relevance to the current population of farmer cooperatives). Using the same databases, we then searched the names of individual cooperatives from certain countries (see Table A1). Considering the qualitative nature of the study, we limited the search to the developed world (i.e., Australia, Europe, North America). Also, many sources only listed the largest cooperatives in select sectors, which implies the study is biased toward relatively large farmer cooperatives in the West. These cooperatives often comprise over $75 \%$ of the total turnover in the cooperative sector, suggesting the sample population is representative in terms of economic activity. In addition, we also performed a separate search of publications in the databases of certain indexed journals and trade magazines which often publish research on farmer cooperatives (see Table A2). We included a particular publication in the study if it presented a dynamic situation by discussing an 
external development in one time-period as well as the response by an existing farmer cooperative in another time period. The search yielded 25 observations of farmer cooperatives which successfully adapted to external developments and remain operational as of early 2018. Corresponding with the exploratory as opposed to the explanatory nature of the study, the evidence is anecdotal as opposed to empirical in nature.

\section{External Adaptation by Farmer Cooperatives}

While addressing the intra-cooperative relationships among members, directors, and managers is important (see [17]), farmer cooperatives must also consider the dynamic external environment if survival is the objective. Dual consideration of internal and external adaptation corresponds to the notion of co-evolution [18,19]. Following Hayek [32] and Williamson [30], external adaptation is in this context defined as the adjustment of strategic characteristics in response to external developments. The study considers four current developments: (i) consolidation among agri-food value chain participants, (ii) segmentation of food consumer preferences, (iii) depression and volatility of commodity prices, and (iv) change in policies and regulations. The list of external developments is not intended to be exhaustive. There exist other relevant developments which warrant attention by future research endeavors.

\subsection{Competition and Consolidation}

Arguably, the most important factor in the external environment is market competition, particularly in light of current developments. From feed and seed manufacturing to food retail, competition at every segment of the agri-food value chain is impacted by ongoing consolidation [8]. In 2007, the food manufacturing sector had an average four-firm concentration ratio (CR4) of 50.3\% and an average Herfindahl-Hirschman Index (HHI) of 1048, which constituted ten-year increases of $13 \%$ and $30 \%$, respectively [36]. Similarly, driven by the expansion of Wal-Mart and other big-box retailers, the CR4 in the food retail sector increased from 17\% to 37\% between 1992 and 2013 [8]. The ongoing consolidation across the agri-food value chain is pressuring farmer cooperatives to improve efficiency or to pursue product differentiation by becoming market-oriented as opposed to user-oriented [9-11]. However, as discussed in the introduction and the background, many farmer cooperatives lack financial flexibility and brand equity to do so. Therefore, as illustrated by the five reviewed publications listed in Table 1, many existing farmer cooperatives pursue external growth by means of horizontal and vertical integration of members as well as non-member business activities.

- Louisiana Sugar Cane Products, a raw sugar marketing cooperative, perceived a gradual loss of bargaining power in the 2000s because of consolidation among raw sugar refineries [37]. By 2009, only two raw sugar refineries operated in the state of Louisiana. As management mistrusted the efficiency of price discovery at the New York Board of Trade and feared exploitation in contractual relationships with sugar refineries, the cooperative engaged in vertical integration to solve its loss of bargaining power. In 2009, the cooperative entered a joint venture with Cargill and Imperial Sugar Company to form Louisiana Sugar Refining, thus taking control of the end product.

- Facing increasing competition from international dairy processors on the domestic market, Finnish dairy cooperative Valio expanded its operations to Sweden, Estonia, and Russia [38]. By 2011, Valio maintained a $40 \%$ share in the fruit yogurt market in Sweden, and 35\% and $55 \%$ shares in the butter markets in Moscow and St. Petersburg, respectively. While its domestic sales decreased by $5 \%$, sales in Sweden and Russia increased by $29 \%$ and $43 \%$, respectively.

- United Agricultural Cooperative, a multi-purpose cooperative in Texas with cotton, grain, agronomy, fuel, and retail departments, faced increasing competition in the agronomy sector from regional and national companies which sold branded products [39]. Unable to compete on price or quality in the agronomy sector, the cooperative sold its input supply business to Pinnacle. 
The divestment of the unprofitable business department facilitated an improvement in the overall profit margin of the cooperative.

- In the 1980s, New Zealand accounted for approximately $60 \%$ of the global kiwi fruit sales [40]. However, because of poor protection of the name "kiwi fruit", farm producers in Chile and Italy began planting kiwi fruit orchards and providing low-cost competition. Unable and unwilling to be price takers on the international market, the Kiwifruit Marketing Board developed the ZESPRI brand to pursue product differentiation. Also, to secure a year-round supply, ZESPRI licensed the use of its new kiwi fruit varieties to growers in Europe and South America to expand its market coverage [41].

- As the largest food retailer in the United States, Wal-Mart has a strong bargaining position in relation to its many suppliers [42]. In the mid-2000s, Wal-Mart mandated its suppliers to make investments in radio frequency identification to improve inventory control. Pacific Coast Producers, which in 2007 sold $\$ 400$ million per year in canned and packaged fruit products to Wal-Mart and other retailers, was one of the few suppliers which implemented the system by deploying the technology on its packing lines and loading doors. Implementing the system allowed the cooperative to increase its sales to Wal-Mart over the next years.

Table 1. Observed Responses to Industry Consolidation by Farmer Cooperatives.

\begin{tabular}{cc}
\hline External Adaptation Method & Example \\
\hline Vertical Integration & Louisiana Sugar Cane Producers \\
Divestment & United Agricultural Cooperative \\
Geographic Expansion & Valio \\
Brand Development & ZESPRI \\
Process Innovation & Pacific Coast Producers \\
\hline
\end{tabular}

\subsection{Consumer Segmentation}

While owned and controlled by farm producers, most farmer cooperatives cannot ignore the indirect or even direct relationship to heterogeneous food consumers. Critical and fragmented food consumers have specific wants and needs in terms of product and process characteristics, such as food safety, shelf life, nutritional value, convenience, and palatability [43]. The ability to address food consumers, manufacturers, or retailers with such wants and needs is dependent on the perceived differentiation in the marketplace. While farmer cooperatives in general do not have a strong market orientation, some farmer cooperatives have adapted to the external developments by means of differentiation and, thus, spurred survival and longevity. However, the six farmer cooperatives listed in Table 2 used various techniques to achieve differentiation: relationship management, portfolio diversification, product and process innovation, and brand development.

- In response to low margins in the New Zealand lamb sector, a local group of 160 sheep farmers came together to find an alternative outlet in the international market [44]. With an equity investment of New Zealand Dollar (NZD) 40,000 per member, the group formed a new generation cooperative, Atkins Ranch, and discovered a niche market for chilled lamb products in the Bay Area of California. Using its network of local relationships, the cooperative responded to sudden changes in product requirements by leading the adoption of new production technologies on the farm operations of its members.

- Formed in 1987, Organic Valley evolved from a small organic produce marketing cooperative in Wisconsin to one of two national organic dairy product manufacturers [45]. As consumer demand for organic food increased, Organic Valley did not only market its member supplies as fluid milk but also pursued opportunities to respond to develop new organic food and drink products, including eggnog, protein powder, yogurt, and more. 
- Euralis, originally formed by French wheat producers in 1936, expanded into food processing in part because of the general trend toward processed food consumption [46]. The cooperative first expanded to the corn sector and subsequently added green beans, sweet peas, and broccoli. Through further diversification, in part accomplished by mergers and acquisitions, the cooperative became a leading producer of foie gras and marketer of corn in Europe. By 2010, farm production contributed less than $50 \%$ of the total revenue of the cooperative.

- Faced by stiff competition from Minute Maid (owned by Coca-Cola) and Tropicana (owned by PepsiCo) in the domestic orange juice market, Florida's Natural uses two credence attributes to differentiate itself [47]. First, the cooperative includes profiles of its orange growers on the side panels of juice cartons to communicate its ownership structure to the consumer. Second, the cooperative also uses commercials and advertisements, as well as labels on its packages, to indicate its juice is made of Florida oranges, which is a registered trademark in the United States.

- Following an increase in the price of almonds, producers added acreage in the early 2000s to increase supply [48]. Anticipating the vast increase in member supply, Blue Diamond recognized a need to develop new almond products. Around the same time, almond demand increased as the public gained awareness of its many health benefits. Since then, Blue Diamond has launched a wide array of new products to cater to different types of consumers and manufacturers, including almond milk, almond flour, and almond snack products. In 2013, the cooperative further emphasized its value-added business activities by establishing the Almond Innovation Center, a research facility with food and drink innovation as its primary purpose.

- In the mid-1980s, beef ranchers struggled to break even as calves only fetched $\$ 0.65$ per pound on the commodity market [49]. In 1986, 14 ranchers in Oregon formed Country Natural Beef to enter a local niche market. Instead of using another feedlot operator, the cooperative added its own feedlot to finish cattle with non-GMO feed. In response to dynamic consumer preferences, the cooperative also added other product attributes related to animal health and land stewardship.

Table 2. Observed Responses to Consumer Segmentation by Farmer Cooperatives.

\begin{tabular}{cc}
\hline External Adaptation Method & Example \\
\hline Relationship Management & Atkins Ranch \\
Portfolio Diversification & Euralis \\
& Organic Valley \\
& Blue Diamond \\
Brand Development & Florida's Natural \\
Vertical Integration & Country Natural Beef \\
\hline
\end{tabular}

\subsection{Price Depression and Volatility}

Commodity prices have been volatile in recent history [50]. The agricultural sector experienced a boom period between 2011 and 2014, but commodity prices then decreased again. In the United States, net cash income in the farm sector decreased by 31\% from $\$ 135.6$ billion in 2013 to $\$ 93.3$ billion in 2016 (U.S. Department of Agriculture Economic Research Service). During the same time period, average farm household income decreased from $\$ 30,639$ to $\$ 24,731$ (-19\%). For U.S. farmer cooperatives, the volatile nature of agricultural prices is reflected in its aggregate performance [4]. As illustrated by the nine reviewed publications, farmer cooperatives have several possible responses to depressed or volatile prices, including closing membership access, managing supply, enforcing collective bargaining, designing long-term contracts, facilitating price discovery, managing inventory, integrating value-added activities, and managing equity structures (see Table 3).

- As supply increased and demand decreased on the organic dairy market, Organic Valley struggled to manage the surplus milk delivered by its members [51]. The organic marketing and processing 
cooperative enforced a series of price reductions to reflect dynamic developments in the consumer marketplace. Meanwhile, the cooperative also closed membership access and established a production quota which allowed delivery of excess milk for $\$ 20$ below the regular pay price.

- In the early 2000s, prices on the fresh potato market did not always exceed the cost of production of approximately $\$ 5$ per hundredweight [52]. In response to the stagnant demand for fresh potatoes, United Potato Growers used supply management to spur price increases. With 2003-2004 as the base period, the program induced supply reduction by levying a $\$ 50$ per acre penalty for members who failed to reduce supply by $15 \%$, and a $\$ 100$ per acre penalty for members who increased supply. The program facilitated an aggregate decline in planted acreage from 415,000 acres in 2000 to 325,000-350,000 acres in 2005-2007. During the next four-year period, growers enjoyed both stable and profitable prices.

- MFA Oil, a supply cooperative in Missouri, lost 70\% of its income source in 2014 as CHS completed a buyout of its partners in the National Cooperative Refinery Association, which operated an oil refinery in Kansas [53]. With extreme price volatility on the raw oil market, MFA Oil adapted its orientation toward external growth in the bulk fuel sector. During the 2014-2016 period, the cooperative used the cash flow generated by the buyout to make over ten acquisitions of private propane suppliers in the Midwest and surrounding states to spur regional expansion.

- From 2018 onwards, Glanbia, the largest dairy cooperative in Ireland, is allowing its members to handle milk price volatility by signing five-year fixed-price milk supply contracts [54]. The long-term contract facilitates $10-100 \%$ of the milk supply to be locked in at $€ 0.31$ per liter. In case of participation in the feed loyalty program, which stipulates feed to be purchased from the cooperative for the five-year period, the contracted milk price increases by $€ 0.02-0.03$ per liter.

- The citrus sector in Valencia, Spain, used to be characterized by the speculative behavior of individual sellers who sold the highest quality on the spot market and the lowest quality to the government or the cooperative [55]. In response, citrus marketing cooperatives formed a second-tier cooperative, Anecoop, to increase the collective export capacity and mitigate the negative effect of speculative behavior by obliging member cooperatives to sell through the collective channel.

- Because of thinness in the local cotton market, Plains Cotton Cooperative Association created an electronic cotton marketing system (TELCOT) in 1975 to reduce information asymmetry and improve price discovery for both buyers and sellers [56]. The system enabled the sellers to include all the relevant information, including the price, the location, and the fiber quality, and the buyers to bargain and purchase remotely. Later, TELCOT became the foundation of The Seam, an online cotton marketplace for growers, cooperatives, merchants, and mills.

- In 2008, many supply cooperatives bought fertilizer in advance of the 2009 growing season at high prices [57]. Then, the value of the inventory decreased as the fertilizer price crashed in early 2009, thus exposing many of the supply cooperatives to substantial risk. In response, Harvest Land Cooperative in Minnesota changed its system of buying and selling fertilizer by transitioning to a weekly market as opposed to a seasonal market, thus decreasing its exposure to extreme volatility in prices.

- In the late 1990s, producers of sugarbeet in the Mountain region of the United States had been receiving relatively low prices from Western Sugar Company, a regional sugar refinery and processor [58]. In 1996, Mountain States Beet Growers Association, the bargaining association owned by the producers, had secured an average price of $\$ 39.90$ per ton. In the next four years, the price increased up to $\$ 48.10$ per ton and then decreased again to $\$ 40.40$ per ton as the processor did not improve its margins in the competitive industry. When its parent organization offered Western Sugar Company for sale, the producers formed a new generation cooperative, Rocky Mountain Sugar Growers Cooperative, to purchase the factories and integrate the refining and processing of sugar.

- The global recession in 2008 decreased milk demand both domestically and internationally, forcing dairy cooperatives to respond to lower prices [59]. Instead of supply management, Michigan 
Milk Producers Association used its capital structure to help members survive the down market. While maximizing the pay price to the best of its ability, the cooperative also increased its monthly advance payments and expedited its patronage cash refunds and equity retirements.

Table 3. Observed Responses to Price Depression and Volatility by Farmer Cooperatives.

\begin{tabular}{cc}
\hline External Adaptation Method & Example \\
\hline Closed Membership Access & Organic Valley \\
Production Quota & United Potato Growers \\
Geographic Expansion & MFA Oil \\
& Glanbia \\
Supply Commitment & Anecoop \\
Price Discovery Enhancement & Plains Cotton Cooperative Association \\
Inventory Management & Harvest Land Cooperative \\
Vertical Integration & Rocky Mountain Sugar Growers Cooperative \\
Equity Management & Michigan Milk Producers Association \\
\hline
\end{tabular}

\subsection{Policy Change}

Most countries use multiple policy instruments to regulate the agricultural sector with various objectives. Considering its primary purpose of correcting market failures to benefit both producers and consumers, farmer cooperatives in particular have received much public policy support [60]. In the European Union, the European Commission spurs a favorable policy environment for the formation and development of farmer cooperatives [61]. The same situation is observed in the United States, where farmer cooperatives enjoy antitrust exemption and single taxation treatment. However, the political environment is volatile, and most countries have reduced or removed trade policy instruments to promote free trade. Over time, farmer cooperatives have used various strategies to extract rent on the international market and protect rent on the domestic market, as exemplified by the five farmer cooperatives listed in Table 4.

- Formed only a year earlier through the merger of three companies, dairy cooperative Fonterra represented $96 \%$ of the dairy producers in the country [62]. As the global market opened with fewer treaties, regulations, and agreements, the cooperative emphasized the export of bulk dairy products (skimmed milk powder and butter) as well as niche and value-added products. To do so, Fonterra formed partnerships with various companies: Swiss multinational Nestle to sell dairy ingredients in North and South America, Australian cooperative Bonlac, Danish cooperative Arla to sell yellow fats in the United Kingdom, and U.S. cooperative Dairy Farmers of America to produce milk protein concentrates in the United States.

- In anticipation of the abolition of the European quota system, French dairy cooperative Sodiaal implemented a two-tier milk pricing structure in 2011 [63]. To discourage overproduction, the cooperative offered an " $\mathrm{A}$ " price for a given volume and a " $\mathrm{B}$ " price for a higher volume related to the volatile world price. At the same time, the cooperative invested in its plant capacity to process the projected increase in milk delivered by its members. The cooperative further managed volatility with futures and derivatives.

- Since the 1960s, the European Union supported the sugar industry with import restrictions, export subsidies, and production quotas. As the European Union began reforming its sugar policy in the early 2000s, Tereos pursued a strategy of geographic expansion [64]. Specifically, Tereos entered the Brazilian market through the acquisition of Guarani in 2003. The cooperative also diversified its product portfolio by manufacturing starch and ethanol.

- As the European Union moved toward abolishing the milk quota system in 2014, Belgian dairy cooperative Milcobel began expanding its processing facility in 2012 to be able to handle the projected growth in milk production by its members [65]. The cooperative made large investments in milk drying and cheese manufacturing, increasing its capacity to 15,000 tons of mozzarella. 
- In 1999, the United States implemented a three-year tariff-rate quota on lamb meat to protect domestic lamb producers [66]. However, Australia and New Zealand filed complaints at the World Trade Organization, which ruled against the United States. As trade re-opened, lamb producers once again faced stiff competition from lamb producers in Australia and New Zealand who exported high-quality lamb products to the United States. To survive, lamb producers in the Northwest formed Mountain States Lamb Cooperative, a new generation cooperative with dual ownership by farmers and investors. The cooperative soon formed a joint venture with a lamb and veal distributor which controlled $25 \%$ of the market. Part of the alliance comprised a quality grid pricing system to induce high-quality production, thus improving the ability of the lamb producers to compete with imported lamb products.

Table 4. Observed Responses to Policy Change by Farmer Cooperatives.

\begin{tabular}{cc}
\hline External Adaptation Method & Example \\
\hline Geographic Expansion & Fonterra \\
& Tereos \\
Variable Pricing Structure & Sodiaal \\
Vertical Integration & Milcobel \\
& Mountain States Lamb Cooperative \\
\hline
\end{tabular}

\section{The Relationship of Strategy to Cooperative Ownership, Governance, and Finance}

While static and incomplete, various typologies of ownership and governance characteristics have captured external adaptation by farmer cooperatives. In the farmer cooperative sector, there exist approximately a dozen common structures with various configurations of ownership characteristics [67-69]. For many hybrid ownership structures, the explicit presence of market- or investor-oriented objectives is manifested by capital-seeking subsidiaries [68]. Similarly, Bijman et al. [70] and Chaddad and Iliopolous [71] advanced typologies with control delegation among members, directors, and managers as the main variable. Many modern farmer cooperatives use a corporate model in which effective control is delegated from board directors to professional decision specialists with specific business knowledge. Altogether, the typologies offer a static representation of the gradual departure from pure user-owned and user-controlled business organizations formed to combat imperfect competition in input supply and output demand sectors. With internal and external adaption, hybrid structures appear to facilitate the pursuit or management of both user- and investor-oriented objectives to balance use and competitiveness [72]. Overall, the evidence is indicative of an organizational form which is diverse and flexible in its characteristics [73]. For farmer cooperatives facing internal as well as external developments, this flexibility is necessary to spur survival and longevity.

While in theory external adaptation is expected to increase the probability of survival and longevity, external adaptation may also signal a gradual transition toward pure investor ownership. There exist several examples of farmer cooperatives which pursued a market orientation and forfeited the cooperative ownership structure at some later point [74]. One such example is Calavo [75], an avocado marketing cooperative in California which in the 1980s began purchasing non-member avocados to assume an export orientation. By 1999, Calavo controlled $40 \%$ of the production in California, but also $35 \%$ and $30 \%$ of imported avocados from Chile and Mexico, respectively. Considering its brand strategy and specific investment in vertical integration, Calavo appeared to pursue investor-oriented as opposed to member-oriented objectives. In 2001, membership voted in favor of conversion to a public corporation. Another example is Diamond Walnut Growers [76], a Californian walnut marketing cooperative which appeared to have embarked on the path toward conversion by hiring an investor-oriented chief executive officer (CEO) in 1998. In the same year, the cooperative formed a new subsidiary financed with $\$ 15$ million in cumulative securities from an institutional investor. The cooperative soon made investments in new product development, in part by sourcing other nut varieties from non-members. In 2004, Diamond 
Walnut Growers introduced its Emerald of California snack nut line on the national market, and a year later the cooperative converted to a public corporation to better pursue its value-added strategies.

As indicated by the examples of Calavo and Diamond Walnut Growers, the pursuit of investor-oriented objectives may facilitate an equity problem as organizational growth requires investments. The same problem instigated the conversions of Dakota Growers Pasta Company and other new generation cooperatives in the late 1990s and early 2000s [77,78]. Of course, there exist many more farmer cooperatives which conduct value-added business activities while making minimal sacrifices in member ownership and member control. In 2004, Ocean Spray rejected an offer by PepsiCo to purchase its brand and juice business [79], and in 2016 the Co-Operative Bulk Handling Group dismissed a hostile takeover attempt by a small group of investors [80]. Arla (dairy), Copersucar (sugar), Cosun (sugar), Danish Crown (meat), and Svenska Lantmännen (grain) are other examples of large farmer cooperatives which continue to survive and succeed as such in spite of responding to external developments with vertical integration, portfolio diversification, geographic expansion, brand development, and similar strategies which may allow the pursuit of investor- as opposed to pure user-oriented objectives. As of yet, there is no applied research to explain why adaptation to internal and external developments may contribute to an eventual exit for one cooperative but not another. Following the logic of organizational co-evolution, however, a possible explanation is the ability to adapt to multiple internal and external developments in dynamic situations. New external developments may warrant further adjustments of strategic characteristics, whereas internal developments may warrant the adjustment of ownership and governance characteristics [18].

\section{Summary and Conclusions}

Farmer cooperatives have been portrayed in the literature as flawed and complex organizations with ambiguous objectives. However, research on the ability of farmer cooperatives to survive in spite of their weaknesses and limitations is scarce, in part because most academic attention to cooperative performance has been static and introspective. Using evidence collected from case studies and print media publications, this paper contributed to the literature with a qualitative study of strategic adaptation by farmer cooperatives in response to various external developments.

The study considered four current external developments in the agri-food industry: industry consolidation, consumer segmentation, price depression and volatility, and policy change. As illustrated by the reviewed publications, farmer cooperatives used various strategies to adapt to dynamic external conditions. For example, Louisiana Sugar Cane Products and Rocky Mountain Sugar Growers used vertical integration to solve the perceived loss of bargaining power as its buyers consolidated. At least three cooperatives (Blue Diamond, Euralis, Organic Valley) responded to the ongoing segmentation of food consumers with product and process innovation to diversify its product portfolios. As two examples of adaptation to price depression and volatility, Organic Valley closed its membership and Plains Cotton Cooperative Association facilitated an enhancement of its price discovery process. Finally, in response to developments in trade policy, farmer cooperatives used various strategies to facilitate rent protection on the domestic market and rent extraction on the international market, such as geographical expansion (Fonterra) and vertical integration (Milcobel). Thus, in spite of various weaknesses and limitations, farmer cooperatives have used various strategies to spur survival and longevity in the agri-food industry. However, farmer cooperatives must beware of possible internal inefficiencies in case of organizational growth. Large farmer cooperatives may have poor social capital and face strong member heterogeneity $[13,81]$, which may facilitate collective action problems [24,25]. Thus, paradoxically, strategic adaptation to spur survival may place farmer cooperatives on an accelerated path toward exit if further adaptation to both internal and external developments is unsuccessful.

More research is certainly needed to explore the causal relationship of strategy to cooperative survival and longevity. It is also worth exploring which strategies form an optimal response to external developments without sacrificing member ownership and member control. As there is no single explanation for business survival or longevity [82], external adaptation ought to be considered in addition 
to other variables. Useful theories and frameworks may include transaction cost theory, agency theory, and the dynamic capabilities view of the firm, among others. Regardless, considering the poor availability of non-aggregated data on farmer cooperatives, the case study method may prove the best option to further our understanding of cooperative survival.

Conflicts of Interest: The author declares no conflict of interest.

\section{Appendix A}

Table A1. List of Countries Included in the Search Strategy.

\begin{tabular}{cc}
\hline Country & Source \\
\hline Australia & Co-operative Development Services \\
Belgium & Nationale Raad voor de Coöperatie \\
Denmark & Danish Agriculture and Food Council \\
Finland & Confederation of Finnish Cooperatives \\
France & COOP de France \\
Germany & Deutscher Raiffeisenverband \\
Greece & Gaia Epicheirein \\
Ireland & Irish Co-operative Organisation Society \\
Italy & Alleanza delle Cooperative Italiane Agroalimentare \\
Netherlands & Nationale Coöperatieve Raad \\
New Zealand & Cooperative Business New Zealand \\
Spain & Cooperativas Agroalimentarias de España \\
Sweden & Lantbrukarnas Riksförbund \\
United Kingdom & Co-operatives UK \\
United States of America & U.S. Department of Agriculture \\
\hline
\end{tabular}

\section{Appendix B}

Table A2. List of Searched Journals.

\begin{tabular}{c}
\hline Agribusiness: An International Journal \\
\hline Agricultural and Resource Economics Review \\
Agricultural Economics \\
Agricultural Finance Review \\
American Journal of Agricultural Economics \\
Annals of Public and Cooperative Economics \\
Applied Economic Perspectives and Policy \\
British Food Journal \\
Canadian Journal of Agricultural Economics \\
Case Study Research Journal \\
European Review of Agricultural Economics \\
Feed and Grain \\
Food Policy \\
Harvard Business Review \\
Journal of Agribusiness \\
International Food and Agribusiness Management Review \\
Journal of Agricultural and Applied Economics \\
Journal of Agricultural and Resource Economics \\
Journal of Agricultural Economics \\
Journal of Business Research \\
Journal of Chain and Network Science \\
Journal of Cooperatives \\
Journal of Food Distribution Research \\
Journal of Rural Cooperation \\
Progressive Farmer \\
Review of Agricultural Economics \\
Rural Cooperatives \\
\hline
\end{tabular}




\section{References}

1. Valentinov, V. Why are cooperatives important in agriculture? An organizational economics perspective. J. Inst. Econ. 2007, 3, 55-69. [CrossRef]

2. Bijman, J.; Iliopoulos, C.; Poppe, K.J.; Gijselinckx, C.; Hagedorn, K.; Hanish, M.; van der Sangen, G. Support for Farmers' Co-Operatives; Final Report; European Commission: Brussels, Belgium, 2012.

3. Cooperatives Europe. The Power of Cooperation; Cooperatives Europe: Brussels, Belgium, 2016.

4. United States Department of Agriculture. Cooperative statistics 2015. In Rural Development Service Report 79; United States Department of Agriculture: Washington, DC, USA, 2017.

5. International Co-Operative Alliance. Blueprint for a Cooperative Decade; International Co-Operative Alliance: Brussels, Belgium, 2017.

6. Grashuis, J.; Su, Y. A review of the empirical literature on farmer cooperatives: Performance, ownership and governance, finance, and member attitude. Ann. Public Coop. Econ. 2018; forthcoming.

7. Cook, M.L.; Grashuis, J. Cooperative theory: Recent developments. In The Routledge Handbook of Agricultural Economics; Routledge: London, UK, 2018; forthcoming.

8. Saitone, T.L.; Sexton, R.J. Concentration and consolidation in the US food supply chain: The latest evidence and implications for consumers, farmers, and policymakers. Fed. Reserve Bank Kansas City Econ. Rev. 2017, 102, 25-59.

9. Briggeman, B.C.; Jacobs, K.L.; Kenkel, P.; McKee, G. Current trends in cooperative finance. Agric. Financ. Rev. 2016, 76, 402-410. [CrossRef]

10. Trienekens, J.; van Velzen, M.; Lees, N.; Saunders, C.; Pascucci, S. Governance of market-oriented fresh food value chains: Export chains from New Zealand. Int. Food Agribus. Manag. Rev. 2017, 1-20. [CrossRef]

11. Grashuis, J. Branding by farmer cooperatives: An empirical study of trademark ownership. J. Co-Op. Org. Manag. 2017, 5, 57-64. [CrossRef]

12. Grashuis, J.; Magnier, A. Product differentiation by marketing and processing cooperatives: A choice experiment with cheese and cereal products. Agribusiness 2018. [CrossRef]

13. Höhler, J.; Kühl, R. Dimensions of member heterogeneity in cooperatives and their impact on organization-A literature review. Ann. Public Coop. Econ. 2017. [CrossRef]

14. Iliopoulos, C.; Valentinov, V. Member preference heterogeneity and system-lifeworld dichotomy in cooperatives: An exploratory case study. J. Org. Chang. Manag. 2017, 30, 1063-1080. [CrossRef]

15. Eversull, E. Number of Ag co-ops celebrating 100th anniversaries on the rise. Rural Cooperatives 2014, 81, 18-23.

16. Merlo, C. Crossing the merger finish line. Rural Cooperatives 2017, 84, 4-9.

17. Cook, M.L.; Iliopoulos, C. Generic solutions to coordination and organizational costs: Informing cooperative longevity. J. Chain Netw. Sci. 2016, 16, 19-27. [CrossRef]

18. Abatecola, G.; Belussi, F.; Breslin, D.; Filatotchev, I. Darwinism, organizational evolution and survival: Key challenges for future research. J. Manag. Gov. 2016, 20, 1-17. [CrossRef]

19. McCarthy, I.P.; Collard, M.; Johnson, M. Adaptive organizational resilience: An evolutionary perspective. Curr. Opin. Environ. Sustain. 2017, 28, 33-40. [CrossRef]

20. Jensen, M.C.; Meckling, W.H. Theory of the firm: Managerial behavior, agency costs, and ownership structure. In Economics Social Institutions; Springer: Dordrecht, The Netherlands, 1979; pp. 163-231.

21. Vitaliano, P. Cooperative enterprise: An alternative conceptual basis for analyzing a complex institution. Am. J. Agric. Econ. 1983, 65, 1078-1083. [CrossRef]

22. Staatz, J.M. The structural characteristics of farmer cooperatives and their behavioral consequences. Coop. Theory New Approaches 1987, 18, 33-60.

23. Porter, P.K.; Scully, G.W. Economic efficiency in cooperatives. J. Law Econ. 1987, 30, 489-512. [CrossRef]

24. Cook, M.L. The future of US agricultural cooperatives: A neo-institutional approach. Am. J. Agric. Econ. 1995, 77, 1153-1159. [CrossRef]

25. Cook, M.L.; Burress, M.J. A Cooperative Life Cycle Framework. Available online: http:/ / departments.agri. huji.ac.il/economics/en/events/p-cook.pdf (accessed on 10 December 2017).

26. Mérel, P.; Saitone, T.L.; Sexton, R.J. Cooperative stability under stochastic quality and farmer heterogeneity. Eur. Rev. Agric. Econ. 2015, 42, 765-795. [CrossRef] 
27. Bijman, J. Agricultural cooperatives and market orientation: A challenging combination. In Market Orientation: Transforming Food and Agribusiness around the Customer; Gower Publishing: London, UK, 2010; pp. 119-136.

28. Hardesty, S.D. Cooperatives as marketers of branded products. J. Food Distrib. Res. 2005, 36, $237-242$.

29. Challita, S.; Aurier, P.; Sentis, P. Linking branding strategy to ownership structure, financial performance and stability: Case of French wine cooperatives. Int. J. Entrep. Small Bus. 2017. [CrossRef]

30. Williamson, O.E. Comparative economic organization: The analysis of discrete structural alternatives. Adm. Sci. Q. 1991, 36, 269-296. [CrossRef]

31. Barnard, C. The Functions of the Executive; Harvard University Press: Cambridge, MA, USA, 1938.

32. Hayek, F.A. The use of knowledge in society. Am. Econ. Rev. 1945, 35, 519-530.

33. Breslin, D. What evolves in organizational co-evolution? J. Manag. Gov. 2016, 20, 45-67. [CrossRef]

34. Bamiatzi, V.; Bozos, K.; Cavusgil, S.T.; Hult, G.T.M. Revisiting the firm, industry, and country effects on profitability under recessionary and expansion periods: A multilevel analysis. Strateg. Manag. J. 2016, 37, 1448-1471. [CrossRef]

35. Abatecola, G. Research in organizational evolution. What comes next? Eur. Manag. J. 2014, 32, $434-443$. [CrossRef]

36. Crespi, J.M.; Saitone, T.L.; Sexton, R.J. Competition in US farm product markets: Do long-run incentives trump short-run market power? Appl. Econ. Perspect. Policy 2012, 34, 669-695. [CrossRef]

37. Gunderson, M.; Johnson, A.; Salassi, M.; Champagne, L.; DeVuyst, C. Determining the future for Louisiana Sugar Cane Products, Inc.: A case study analyzing vertical coordination options. J. Cooperatives 2009, 22, 1-22.

38. Ollila, P.; Pyykkönen, P. Support for Farmers Cooperatives: Case Study Report Valio; Wageningen UR: Wageningen, The Netherlands, 2012.

39. Siebert, J.W.; Park, J.L. United Agricultural Cooperative: Considering the sale of the agronomy division. Int. Food Agribus. Manag. Rev. 2017, 1-10. [CrossRef]

40. Beverland, M. Creating value through brands: The ZESPRI kiwi fruit case. Br. Food J. 2001, 103, $383-399$. [CrossRef]

41. Beverland, M. Can cooperatives brand? Exploring the interplay between cooperative structure and sustained brand marketing success. Food Policy 2007, 32, 480-495. [CrossRef]

42. Weier, M. Supplier likes what it's getting from Wal-Mart's RFID push. Information Week, 17 September 2007.

43. Grunert, K.G. Food quality and safety: Consumer perception and demand. Eur. Rev. Agric. Econ. 2005, 32, 369-391. [CrossRef]

44. Goldsmith, P.; Gow, H. Strategic positioning under agricultural structural change: A critique of long jump co-operative ventures. Int. Food Agribus. Manag. Rev. 2005, 8, 1-21.

45. Su, Y.; Cook, M.L. Price stability and economic sustainability-achievable goals? A case study of Organic Valley. Am. J. Agric. Econ. 2015, 97, 635-651. [CrossRef]

46. Cohen, M.L. French cooperatives mean business: Evolving strategies for the global food marketplace. In Case Studies in Global Business; Gale, Cengage Learning: Detroit, MI, USA, 2011; pp. 97-107.

47. Campbell, D. Failure is not an option. Rural Cooperatives 2017, 84, 8-13.

48. Carol, B. Blue Diamond Says Aggressive Product Development Needed. Western Farm Press. 21 January 2006. Available online: http:/ / theclippermag.com/index.php/featured/blue-diamond-grower-seeks-moneyexport-promotion/ (accessed on 11 December 2017).

49. Ishmael, W. Matching consumer to rancher. Beef 2008, 44, 28-32.

50. Baffes, J.; Haniotis, T. What explains agricultural price movements? J. Agric. Econ. 2016, 67, 706-721. [CrossRef]

51. Abbate, L. Organic dairy farmers 'weathering the storm' as milk prices drop, production quotas set. Bangor Daily News, 23 September 2017.

52. Guenthner, J. The development of United Potato Growers cooperatives. J. Cooperatives 2012, 26, 1-16.

53. Casteel, K. Momentum. Inside Columbia, 23 June 2016.

54. Yates, J. Glanbia introduces five-year fixed milk price contract. Farmers Weekly, 25 August 2017.

55. Gallego-Bono, J.R.; Chaves-Avila, R. Innovation cooperative systems and structural change: An evolutionary analysis of Anecoop and Mondragon cases. J. Bus. Res. 2016, 69, 4907-4911. [CrossRef]

56. Welch, J.M.; Lyford, C.P.; Harling, K. The Value of Plains Cotton Cooperative Association. Rev. Agric. Econ. 2007, 29, 170-185. [CrossRef] 
57. Campbell, D. Passing the stress test. Rural Cooperatives 2009, 76, 4-8.

58. Brester, G.W.; Boland, M.A. The Rocky Mountain Sugar Growers' Cooperative: "Sweet" or "sugar-coated" visions of the future? Rev. Agric. Econ. 2004, 26, 287-302. [CrossRef]

59. Campbell, D. Storm shelter. Rural Cooperatives 2009, 76, 8-13.

60. Iliopoulos, C. Public policy support for agricultural cooperatives: An organizational economics approach. Ann. Public Cooperatives Econ. 2013, 84, 241-252. [CrossRef]

61. Brusselaers, J.; Poppe, K.; Azcarate, T.G. Do policy measures impact the position and performance of farmers' cooperatives in the EU? Ann. Public Cooperatives Econ. 2014, 85, 531-553. [CrossRef]

62. Goldberg, R.A.; Porraz, J.M. Fonterra: Taking on the dairy world. In Harvard Business School Case 903-413; Harvard University Press: Cambridge, MA, USA, 2003.

63. Pitman, L. Sodiaal constantly adapts to changing EU and global dairy foods markets. Rural Cooperatives 2017, 84, 26-27.

64. Filippi, M.; Kühl, R.; Smit, B. Support for Farmers Cooperatives: Case Study Report Cosun, Südzucker/Agrana, Tereos; Wageningen UR: Wageningen, The Netherlands, 2012.

65. Dairy Industries International. Milcobel ready for post-quota. Dairy Ind. Int. 2012, 77, 9.

66. Boland, M.A.; Bosse, A.; Brester, G.W. The Mountain States Lamb Cooperative: Can vertical integration keep lamb producers from being fleeced? Rev. Agric. Econ. 2007, 29, 157-169. [CrossRef]

67. Chaddad, F.R.; Cook, M.L. Understanding new cooperative models: An ownership-control rights typology. Appl. Econ. Perspect. Policy 2004, 26, 348-360. [CrossRef]

68. Cook, M.L.; Chaddad, F.R. Redesigning cooperative boundaries: The emergence of new models. Am. J. Agric. Econ. 2004, 86, 1249-1253. [CrossRef]

69. Grashuis, J.; Cook, M.L. Toward an updated typology of U.S. farmer cooperatives: Survey evidence of recent hybrid ownership restructuring. In Management and Governance of Networks: Franchising, Cooperatives and Strategic Alliances; Hendrikse, G., Cliquet, G., Ehrmann, T., Windsperger, J., Eds.; Springer: Heidelberg, Germany, 2017; pp. 149-170.

70. Bijman, J.; Hendrikse, G.; Oijen, A. Accommodating two worlds in one organisation: Changing board models in agricultural cooperatives. Manag. Decis. Econ. 2013, 34, 204-217. [CrossRef]

71. Chaddad, F.; Iliopoulos, C. Control rights, governance, and the costs of ownership in agricultural cooperatives. Agribusiness 2013, 29, 3-22. [CrossRef]

72. Cook, M.L.; Plunkett, B. Collective entrepreneurship: An emerging phenomenon in producer-owned organizations. J. Agric. Appl. Econ. 2006, 38, 421-428. [CrossRef]

73. Chaddad, F. Advancing the theory of the cooperative organization: The cooperative as a true hybrid. Ann. Public Cooperatives Econ. 2012, 83, 445-461. [CrossRef]

74. Fulton, M.E.; Hueth, B. Cooperative conversions, failures and restructurings: An overview. J. Cooperatives 2009, 23, 1-11.

75. Stanford, L.; Hogeland, J.A. Designing organizations for a globalized world: Calavo's transition from cooperative to corporation. Am. J. Agric. Econ. 2004, 86, 1269-1275. [CrossRef]

76. Hardesty, S.D. The conversion of Diamond Walnut Growers. In Cooperative Conversions, Failures and Restructurings: Case Studies and Lessons from U.S. and Canadian Agriculture; Knowledge Impact in Society: Saskatoon, Saskatchewan, 2009; pp. 39-52.

77. Boland, M.; McKee, G. The restructuring of Dakota Growers Pasta Company. In Cooperative Conversions, Failures and Restructurings: Case Studies and Lessons from U.S. and Canadian Agriculture; Knowledge Impact in Society: Saskatoon, Saskatchewan, 2009; pp. 143-154.

78. Grashuis, J.; Cook, M.L. An examination of new generation cooperatives in the Upper Midwest: Do producer-owned organizations have a future in the value-added agri-food industry? Presented at the North Central Extension Research Activities 210 Annual Meeting-NCERA-210, St. Paul, MN, USA, 1 November 2017.

79. Hogeland, J. Co-op conversions. Rural Cooperatives 2006, 73, 17-20, 30-31.

80. Hemphill, P. Grower survey backs $\mathrm{CBH}^{\prime}$ s rejection of Champion takeover bid. The Weekly Times, 25 April 2016.

81. Nilsson, J.; Svendsen, G.L.; Svendsen, G.T. Are large and complex agricultural cooperatives losing their social capital? Agribusiness 2012, 28, 187-204. [CrossRef] 
82. Napolitano, M.R.; Marino, V.; Ojala, J. In search of an integrated framework of business longevity. Bus. Hist. 2015, 57, 955-969. [CrossRef] 